\title{
PEMANFAATAN INFUSA BUAH JERNANG (Daemonorops draco Bl.)TERHADAP BAKTERI ESCHERICHIA COLI SEBAGAI OBAT ANTIDIARE PADA SUKU TALANG MAMAK PROVINSI RIAU
}

\author{
Putri Cristine $^{\mathbf{1}}$,Silviana Ramaloka ${ }^{1}$ ) \\ ${ }^{1}$ Sekolah Menengah Kesehatan AbdurrabPekanbaru, Indonesia \\ email:rmlksilvia@gmail.com
}

\begin{abstract}
Indonesia is an archipelago which is built by various tribes and religions These tribes inhabit the islands scattered throughout Indonesia. Today various fields of medicine are increasingly experiencing development, including traditional medicine. The purpose of this study was to determine the zone of inhibition of Jernang fruit infusion (Daemonorops draco B1) in inhibiting the growth of Escherichia coli in vitro and to prove whether the Jernang fruit infusion used by the Talang Mamak tribe in Bukit Thirty of Riau Province can be used as an antidiarrheal drug. The study was conducted using the experimental laboratory method in vitro. The results showed the average value of inhibition zone in Jernang fruit infusion was $9.7 \mathrm{~mm}$, the average value of inhibition zone of ciprofloxacin antibiotics was $35.7 \mathrm{~mm}$ (positive control) and $0.9 \% \mathrm{NaCl}$ sterile no zone of inhibition (negative control). it can be concluded that Jernang fruit infusion (Daemonorops dracoBl.) It has an active substance with an inhibition zone diameter of $20 \mathrm{~mm}$ and this proves that jernang fruit infusion can be used as an anti-diarrhea medicine because it contains active compounds such as flavonoids, tannins, saponins, and steroids / triterpenoids.
\end{abstract}

Keywords: Jernang fruit infusa (Daemonorops dracoB1.), Talang Mamak, Escherichia coli

\begin{abstract}
ABSTRAK
Indonesia merupakan negara kepulauan yang dibangun oleh berbagai suku dan agama.Suku-suku ini mendiami pulau-pulau yang tersebar di seluruh Indonesia.Dewasa ini berbagai bidang pengobatan semakin mengalami perkembangan, termasuk pengobatan tradisional. Tujuan dari penelitian ini adalah untuk menentukan zona hambat infusa buah jernang (Daemonorops draco Bl) dalam menghambat pertumbuhan Escherichia coli secara in vitro dan untuk membuktikan apakah infusa buah jernang yang digunakan suku Talang Mamak di Bukit Tiga Puluh Provinsi Riau dapat digunakan sebagai obat antidiare .Penelitian dilakukan dengan metode eksperimental laboratory in vitro. Hasil penelitian menunjukkan nilai rata-rata zona hambat infus buah jernang adalah $9,7 \mathrm{~mm}$, nilai rata-rata zona hambat antibiotik Ciprofloksasin 35,7 mm (kontrol positif) dan $\mathrm{NaCl}$ steril 0,9\% tidak ada zona hambat (kontrol negatif). Dapat disimpulkan infus buah jernang (Daemonorops dracoBl.) memiliki zat aktif dengan diameter zona hambat $20 \mathrm{~mm}$ dan hal ini membuktikan infusa buah jernang dapat digunakan sebagai obat anti diare karena mengandung senyawa aktif seperti flavonoid, tanin, saponin, dan steroid / triterpenoid.
\end{abstract}

Kata kunci: Infusa Buah Jernang (Daemonorops dracoBl.), Talang Mamak, Escherichia coli 


\section{PENDAHULUAN}

Indonesia merupakan negara kepulauan yang memiliki beragam suku dan kebudayaan.keberagaman suku ini mendiami pulau-pulau yang tersebar di seluruh wilayah Indonesia.Beragamnya suku yang ada di Indonesia, menjadikan negara ini memiliki ragam budaya dan kearifan lokal. Berdasarkan hasil dari kerjasama Badan Pusat Statistik (BPS) dan Institute of South Asian Studies (ISEAS) menyebutkan bahwa terdapat sekitar 633 suku yang diperoleh dari pengelompokan suku dan subsuku yang ada di Indonesia.

Undang-undang nomor 5 tahun 2017 tentang pemajuan kebudayaan yang dikeluarkan Pemerintah Pusat sejalan dengan dukungan penuh untuk visi Riau 2020. Sebagaimana visi Riau menjadikan Riau sebagai pusat kebudayaan melayu Asia Tenggara. Undang-undang nomor 5 tahun 2017 Pada pasal 5 menyebutkan bahwa objek pemajuan kebudayaan meliputi tradisi lisan, manuskrip, adat istiadat, ritus, teknologi tradisional,pengetahuan tradisional, seni, bahasa permainan rakyat dan olahraga tradisional.

Provinsi Riau merupakan provinsi yang memiliki berbagai macam suku bangsa, salah satunya adalah Suku Talang Mamak. Suku Talang Mamak merupakan keturunan dari bangsa proto melayu atau melayu tua (Ras Paleo-Mongoloid) yang terletak di Kabupaten Indragiri Hulu dan Kabupaten. Indragiri Hilir Provinsi Riau, kehidupan suku Talang Mamak sangat bergantung pada hutan dan ladang. Semua kebutuhan hidup suku Talang Mamak sudah terpenuhi dari alam sekitarnya mulai dari makanan, minum bahkan sampai obat-obatan. Selain itu, masyarakat Talang Mamak juga memiliki sistem pengetahuan dibuktikan dengan pemanfaatan tumbuhan sebagai obat(Islamuddin, 2014)

Berdasarkan hasil Ekspedisi Biota Medika (1998) menunjukkan bahwa Suku Talang Mamak mampu memanfaatkan 110 jenis tumbuhan untuk mengobati 56 jenis penyakit dan mengenali 22 jenis cendawan obat. Salah satu tanaman yang berkhasiat obat yang sering suku Talang Mamak gunakan adalah buah jernang, karena dapat mengobati diare, obat luka, disentri, serbuk untuk gigi, asma, sipilis, berkhasiat apbrodisiac serta pembeku darah karena luka.(Waluyo, 2008)

Kandungan kimia utama yang terkandung dalam buah Jernang adalah resin ester dan drakoresinotanol (57-82\%). Resin yang berwarna merah mengandung senyawa-senyawa seperti drakoresena (14\%),residu (18,4\%), drakoalban (hingga 2,5\%) resin tak larut $(0,3 \%)$, asam benzoilasetat, flavonoid,, saponin, tannin, steroid/triterpenoid dan beberapa pigmen terutama drakorhodin dan nordrakorhodin.(Purwanto et al, 2005)

Hasil uji aktivitas antiosidan dan aktikoagulasi resin buah Jernang menunjukkan bahwa tiga jenis Jernang yang diekstrak menggunakan pelarut polar (methanol) dan semi polar ( etil asetat) mengandung golongan senyawa yang dikenal peruntukannya sebagai obat-obatan yaitu flavonoid, tannin, dan triterpenoid serta berpotensi sebagai antioksidan(Waluyo, T.K., dan Pasaribu, 2013).

Penggunaan tumbuhan obat sebagai obat tradisional yang digunakan oleh masyarakat dikarenakan tanaman obat mudah didapat, harganya murah dan tidak mempunyai efek samping bila digunakan.Hal ini bertolak belakang dengan penggunaan obat medis dikarenakan harganya mahal dan mempunyai efek samping bila digunakan.

Berdasarkan latar belakang di atas penulis tertarik untuk melakukan penelitian mengenai uji daya hambat infusa buah Jernang (Daemonorops draco Bl.) terhadap bakteri Escherichia coli sebagai obat tradisional antidiare Pada Masyarakat Suku Talang Mamak di Bukit Tiga Puluh Provinsi Riau Secara in vitro 


\section{METODE}

\section{Alat dan Bahan}

Alat yang digunakan adalah timbangan analitik, autoclave, Oven, hote plate, Waterbath, gelas ukur, erlenmeyer, lampu spritus, labu ukur, pipet ukur, gelas objek, ose cincin, mikroskop, inkubator, batang pengaduk, kapas, disk kosong, spatula, tabung reaksi, rak tabung reaksi, cawan petri, kompor gas, jangka sorong, dan kapas lidi steril.

Bahan-bahanyang digunakan dalam penelitian ini yaitu buah Jernang yang diambil di Bukit Tiga Puluh Provinsi Riau, strain Escherichia coli, $\mathrm{NaCl}$ 0,9\% steril (kontrol negatif), larutan standard MC. Farland ( $\mathrm{H} 2 \mathrm{SO} 41 \%$ dan $\mathrm{BaCl} 21.175 \%$ ) dandisk antibiotik ciprofloxacin (kontrol positif), alkohol 70\% dan media yang digunakan yaitu Muller Hinton Agar (MHA).

\section{Metode}

1. Pembuatan Infusa Buah Jernang $10 \%$

Kupas buah Jernang dari kulitnya, kemudian dirajang, lalu ditimbang 10 gram bahan rajangan tersebut dan dimasukkan ke dalam beacker glassdan ditambahkan $100 \mathrm{ml}$ aquadest, lalu dipanaskan di atas waterbath mulai suhu $90^{\circ} \mathrm{C}$ sambil sekali-kali diaduk selama 15 menit, setelah cukup waktu angkat dan saring (Depkes, 2000)

2. Pembuatan Larutan Standar MC. Farlan

Larutan $\mathrm{H}_{2} \mathrm{SO}_{4} 1 \%$ dipipet sebanyak $9 \mathrm{ml}$, dimasukkan ke dalam tabung reaksikemudian ditambahkan larutan $\mathrm{BaCl}_{2} 2 \mathrm{H}_{2} \mathrm{O}$ 1,175\% sebanyak $1 \mathrm{ml}$, kemudian dihomogenkan (Soemarno, 2000)

3. Pengujian Efektivitas Bakteri

a. Pembuatan Suspensi Bakteri

Diambil satu ujung ose koloni E. coli dari media subkultur, kemudian disuspensikan dalam tabumg yang berisi $\mathrm{NaCl} 0,9 \%$ steril sampai kekeruhannya sama dengan larutan standar Mc. Farland

b. Penanaman Pada Media Muller Hinton Agar

Kapas lidi steril dicelupkan ke dalam suspensi bakteri yang telah distandarisasi kekeruhannya, tunggu sampai meresap ke dalam kapas. Kemudian kapas lidi diangkat dan diperas dengan menekankan pada dinding tabung bagian dalam sambil diputar., lalu oleskan kapas lidi tersebut pada media Muller Hinton Agar plate dengan memutar cawan petri sampai permukaan media tertutup rapat kemudian biarkan Muller Hinton Agar plate selama 5-15 menit supaya suspensi bakteri meresap ke dalam agar-agar.

c. Penempelan Disk

Penempelan pada Muller Hinton Agar plate dilakukan secara manual satu-persatu dengan pinset, ambil kertas disk kosong dan celupkan ke dalam infusa buah Jernang, kemudian letakkan pada permukaan media Muller Hinton Agar plate yang sudah diolesi suspensi E.coli dengan sedikit ditekan kemudian ambil disk ciprofloxacin dan letakkan pada media Muller Hinton Agar plate di sebelah disk infusa buah Jernang, beri penekanan sedikit pada disk tersebut, lalu ambil kertas disk kosong dan celupkan $\mathrm{ke} \mathrm{NaCl}$ 0,9\% steril, kemudian letakkan pada permukaan media Muller Hinton Agar plate di sebelah disk infusa buah Jernang, beri penekanan sedikit pada disk tersebut, pastikan jarak antara disk satu dengan disk lainnya tidak kurang dari $15 \mathrm{~mm}$. kemudian inkubasi dalam inkubator selama $1 \times 24$ jam pada suhu $37^{\circ} \mathrm{C}$. 


\section{d. Pembacaan}

Amati zona hambatan yang terjadi di sekeliling disk dan ukur panjang diameternya dengan jangka sorong., jika terdapat zona hambatan di sekeliling disk infusa buah Jernang $10 \%$, berarti buah Jernang memiliki kandungan zat aktif sebagai antibakteri terhadap E.coli, namun jika tidak terdapat zona hambatan di sekeliling disk infusa buah Jernang 10\%, berarti buah Jerenang tidak memiliki kandungan zat aktif sebagai antibakteri terhadap E.colidan untuk disk ciprofloxacin sebagai kontrol positif harus bersifat sensitif terhadap bakteri E.coli (terjadi zona hambat)

\section{ANALISA DATA}

Analisis data dilakukan dengan cara mengukur diameter zona bening (daya hambat)di sekeliling disk infusa buah Jernang $10 \%$ dan dibandingkan dengan diameter hambatan oleh ciprofloxacin dan $\mathrm{NaCl}$ 0,9\% steril. Data yang diperoleh disajikan dalam bentuk tabel dan dibahas secara deskriptif.

\section{HASIL DAN PEMBAHASAN}

Setelah dilakukan penelitian aktivitas hambatan infusa buah Jernang (D. dracoBl.) terhadap bakteri E. Coli secara In vitro, didapatkan hasil seperti pada tabel di bawah ini :

Tabel I. Hasil Uji Aktivitas Hambatan Infusa Buah Jernang terhadap E. Coli

\begin{tabular}{lcccc}
\hline \multicolumn{1}{c}{ Bahan } & $\begin{array}{c}\text { Diameter } \\
\text { Zona } \\
\text { Hambat }\end{array}$ & $\begin{array}{c}\text { Diameter } \\
\text { Zona } \\
\text { Hambat }\end{array}$ & $\begin{array}{c}\text { Diameter } \\
\text { Zona } \\
\text { Hambat }\end{array}$ & Rerata \\
\hline $\begin{array}{l}\text { Infusa Buah Jernang } \\
\mathbf{1 0} \%\end{array}$ & $10,8 \mathrm{~mm}$ & $8,8 \mathrm{~mm}$ & $9,7 \mathrm{~mm}$ & $9,7 \mathrm{~mm}$ \\
Ciprofloxacin & $34,6 \mathrm{~mm}$ & $35,3 \mathrm{~mm}$ & $37,2 \mathrm{~mm}$ & $35.7 \mathrm{~mm}$ \\
\end{tabular}

\begin{tabular}{cccc} 
NaCl 0,9\% & Tidak ada & Tidak ada & Tidak ada \\
zona & zona & zona \\
hambatan & hambatan & hambatan \\
\hline
\end{tabular}

Keterangan : ukuran diameter disk $=6 \mathrm{~mm}$

Penelitian ini dilakukan sebanyak tiga kali ulangan pengujian dengan hasil diameter hambatan rata-rata yang diperoleh adalah $9,7 \mathrm{~mm}$. Hasil tersebut dibandingkan dengan zona hambat antibiotik cifrofloxacin sebagai kontrol positif dan $\mathrm{NaCl} 0.9 \%$ sebagai kontrol negatif. Bila dibandingkan dengan nilai sensitifitas antibiotik ciprofloxacin yaitu $35,7 \mathrm{~mm}$ terhadap $E$. Coli, sampel yang digunakan dapat dikategorikan sensitif mengahambat pertumbuhan bakteri E. Coli. Hasil pengujian aktivitas antibakteri infusa buah Jernang $10 \%$ dapat dikatakan efektif dalam menghambat pertumbuhan $E$. coli secara in vitro karena mempunyai zona hambat rata-rata yaitu $9,7 \mathrm{~mm}$. Hal ini membuktikan bahwa kemungkinan buah Jernang mengandung zat aktif yang mampu menghambat pertumbuhan bakteri $E$. coli sebagai penyebab diare.

Zat aktif antibakteri dalam buah Jernang seperti resin ester, drakoresinotanol, flavonoid, tannin, saponin, steroid/triterpenoid dapat menghambat proses pertumbuhan bakteri dengan cara sintesis protein sel bakteriE. coli.Bakteri tersebut merupakan salah satu kelompok bakteri Gram negatif.Dinding sel bakteri Gram negatif terdiri atas lapisan peptidoglikan yang tipis dan membran dibagian luar lapisan peptidoglikan.Dinding selnya mengandung sedikit lapisan peptidoglikan dan tidak mengandung asam teikoat, oleh sebab itu dinding sel bakteri Gram negatif lebi rentan terhadap goncangan fisik, seperti pemberian antibiotik atau bahan-bahan antibakteri lainnya (Mpila, Fatimawali and Wiyono, 2012). Senyawa tanin memiliki aktivitas antibakteri, Mekanisme kerja dalam 
menghambat sel bakteri, senyawa tanin akan mendenaturasi protein sel bakteri(Roslizawaty et al., 2013), Selain senyawa tanin, senyawa saponin juga memiliki aktivitas antibakteri. Mekanisme kerja senyawa saponin sebagai antibakteri yaitu dengan cara menyebabkan kebocoran protein dan enzim di dalam sel bakteri (Taufiq, Yuniarni and Hazar, 2015). Cara kerja senyawa steroid sebagai antibakteri berhubungan dengan membran lipid dan sensitivitas terhadap komponen steroid yang menyebabkan kebocoran pada liposom. Steroid dapat berinteraksi dengan membran fosfolipid sel yang bersifat permeabel terhadap senyawa-senyawa lipofilik sehingga menyebabkan integritas membran menurun serta morfologi membran sel berubah yang menyebabkan sel mudah rusak yang kemdian lisis (Madduluri et al, 2013). Sedangkan antibiotik ciprofloxacin terhadap bakteri yaitu dengan caramenyekat sintesis DNA bakteri dengan jalan menghambat topoisomerase II pada bakteri. Penghambatan DNA gyrase akan mencegah relaksasi supercoiled DNA secara positif yang dibutuhkan untuk transkripsi dan replikasi normal.dan menghambat dua tipe enzim topoisomerase II yaitu DNA gyrase dan topoimerarase IV. (Kim and Baik, 2004).Hal ini menunjukkan bahwa infusa buah jernang mampu menghambat pertubuhan E. coli.

\section{KESIMPULAN}

Infusa buah Jernang (Daemonorops draco B1.) dapat menghambat pertumbuhan Escherichia coli dibuktikan dengan adanya zona hambat di sekitar disk Infusa buah Jernang (Daemonorops draco B1.) sebesar 9,7mm dan telah dibuktikan bahwa teknologi tradisional buah Jernang yang dipakai masyarakat suku Talang Mamak di Bukit Tiga Puluh Provinsi Riau dapat dijadikan sebagai obat antidiare yang di uji secara uji In vitro

\section{UCAPAN TERIMAKASIH}

Peneliti mengucapkan terima kasih kepada semua pihak yang telah membantu

\section{REFERENSI}

Depkes, R. 2000. Sediaan Galenik. Jakarta: Departemen Kesehatan RI.

Islamuddin. 2014. Nilai-Nilai Kearifan Lokal Sebagai Civic Culture Pada Budaya Suku Talang Mamak. Bandung: Universitas Pendidikan Indonesia.

Kim, Y. and Baik, H. 2004. TopoisomeraseII and Topoisomerase IV Gene Mutations Fluoroquinolone Resistance of Pseudomonas aeruginosa. 10, pp. 507-514.

Madduluri, S., Babu Rao, K. and Sitaram, B. 2013. In vitro evaluation of antibacterial activity of five indigenous plants extract against five bacterial pathogens of human.International Journal of Pharmacy and Pharmaceutical Sciences, 5(SUPPL.4), pp. 679-684.

Mpila, D. ., Fatimawali and Wiyono, W. I. 2012. Uji Aktivitas Antibakteri Daun Mayana (Coleus atropurpureus [L] Benth) Terhadap Staphylococcus aureus, Escherichia coli dan Pseudomonas aeruginosa secara in-vitro. 1(1), p. 13. doi: https://doi.org/10.35799/pha.1.2012.440.

Purwanto Y, Polosakan Y, Susiarti S, W. E. 2005. Ekstraktivisme Jernang (Daemonorops Spp.) Dan Kemungkinan Pengembangannya: Studi Kasus Di Jambi, Sumatra, Indonesia. Bogor: LIPI.

Roslizawaty. 2013. Aktivitas Antibakterial Ekstrak Etanol Dan Rebusan Sarang Semut (Myrmecodia Sp.) Terhadap Bakteri Escherichia Coli.Jurnal Medika Veterinaria, 7(2), pp. 91-94. doi: 10.21157/j.med.vet..v7i2.2938. 
JOPS (Journal Of Pharmacy and Science)

Vol.4, No.1,Bulan Desember 2020, Hal.7-12

p-ISSN:2622-9919; e-ISSN:2615-1006

Soemarno. 2000. Isolasi dan Identifikasi Bacteri Klinik. Yogyakarta: Departemen Kesehatan RI.

Taufiq, S., Yuniarni, U. and Hazar, S. 2015. Uji Aktivitas Antibakteri Ekstrak Etanol Biji Buah Pepaya (Carica Papaya L.) terhadap Escherichia Coli dan Salmonella Typh, pp. 654-661.

Waluyo, T.K., dan Pasaribu, G. 2013. Aktivitas Antioksidan dan Antikoagulasi Resin Jernang', Jurnal Penelitian Hasil Hutan, 31(4), pp. 306-315. doi: https://doi.org/10.20886/jphh.2013.31.4.306315.

Waluyo, T. 2008. Teknik Ekstraksi Tradisional dan Analisis Sifat-sifat Jernang Asal Jambi, Jurnal Penelitian Hasil Hutan, 26(1), pp. 30-40. doi: https://doi.org/10.20886/jphh.2008.26.1.30-40. 